\title{
VARIASI STRUKTUR VOKALISASI OWA JAWA (Hylobates moloch Audebert, 1798) DI HUTAN LINDUNG PETUNGKRIYONO, PEKALONGAN, JAWA TENGAH
}

\author{
Sity Maida ${ }^{1 *}$, Paskal Sukandar ${ }^{2}$, dan Yossa Istiadii ${ }^{3}$ \\ ${ }^{1}$ Prodi Biologi FMIPA Universitas Negeri Jakarta, Indonesia. ${ }^{2}$ Prodi Pendidikan Biologi FMIPA Universitas \\ Negeri Jakarta, Indonesia. ${ }^{3}$ Prodi Pendidikan Kependudukan dan Lingkungan Hidup, Universitas Pakuan, \\ Bogor, Indonesia \\ *Email: sitymaida@gmail.com
}

\begin{abstract}
Javan gibbon is one of an endemic species of Java with kind of unique vocalizations. Supported by a study which showed that every individual has the different anatomy vocal tract that will produce a different sound. Character vocalizations formed from the structure of vocalizations vary between individuals would be the identity of an individual so that there will be effective communication between the giver signal to the receiver. The objective of research is to find out the structure variation of Javan gibbon vocalizations. The research was accomplished in AugustSeptember 2015 at the Petungkriyono Protected Forest, Pekalongan, Central Java. The method used is the Focal Continuous sampling. Ratio coefficient of variation within and between female, indicates that the variable vocalizations vary between individuals, and the correct rate of individual identification yielded bydiscriminant function analysis using variable vocalizations was satisfactory $(94,4 \%)$. Variable vocalization differentiatoris total great call duration $(8,99-13,53 \mathrm{~s})$, total great call duration excluding termination phase, duration pre-trill phase, duration introduction note $(0,147-0,612 \mathrm{~s})$, frequency range introduction note $(408,54-1209,6 \mathrm{~Hz})$, minimal frequency introduction note, maximal frequency introduction note, minimal frequency second trill note, minimal frequency at end of trill note, and minimal frequency range in trill. These vocalizations potentially allow individual recognition of animals.
\end{abstract}

Key words : Javan gibbon, structure variation of vocalizations, great call, individuality

\section{PENDAHULUAN}

Primata merupakan makhluk sosial yang hidup berkelompok. Untuk dapat berinteraksi antar individu, diperlukan adanya komunikasi. Terdapat berbagai cara untuk melakukan komunikasi. Salah satunya yaitu dengan pemberian sinyal berupa suara atau yang disebut dengan vokalisasi. Primata umumnya hidup di hutan lebat dimana sinyal visual sangat terbatas. Sehingga vokalisasi digunakan satwa khususnya primata, untuk memberi informasi mengenai keberadaan kelompok, panggilan untuk makan, memberi peringatan pada kelompok (alarm call), sinyal yang memprediksi perilaku, menarik pasangan, dan mempertahankan teritorial (Seyfarth et al., 2010).

Penelitian vokalisasi pada primata menjadi sangat penting untuk manajemen konservasi, terutama untuk jenis yang jarang dan sulit untuk ditemui secara langsung. Selain itu, penelitian mengenai vokalisasi juga berguna dan penting dalam memperkirakan kepadatan populasi (Whittaker, 2005; Cheyne, 2008), menduga kekerabatan antar taxa dan bisa merekonstruksi phylogeny, mirip dengan penggunaan atas dasar morfologi (Haimoff et al., 1982 dalam Dallmann dan Geissmann, 2009) dan molekuler yang lebih sering digunakan (Andayani N. et al., 2001 dalam 
Dallmann dan Geissmann, 2009).

Owa jawa termasuk kedalam kelompok Lesser apes (Gibbon), primata endemik Indonesia yang hanya terdapat di Pulau Jawa. Gibbon adalah salah satu kelompok dari primata, yang memiliki ciri khas pada vokalisasinya. Vokalisasi pada Owa jawa berperan sebagai teritorial advertisment, daya tarik untuk kawin, dan untuk mempererat pasangan serta ikatan keluarga dalam satu kelompok (Chivers, 1974). Salah satu tipe vokalisasi pada Owa jawa yaitu Song bout, dikeluarkan hanya oleh betina dewasa dalam kelompok dan menjadi vokalisasi yang paling mencolok dari Owa jawa.

Beberapa studi menunjukan bahwa sinyal komunikasi dapat mengidentifikasi individu khusus sejenis dan membedakan hewan lain berdasarkan signature information (Bee et al., 2001, Arini et al., 2015). Hal tersebut didukung oleh sebuah studi yang menunjukan bahwa setiap individu memiliki anatomi saluran vokal yang berbedabeda sehingga akan memproduksi suara yang berbeda pula (Belin, 2006).

Oleh karena itu, diduga akan terdapat variasi vokalisasi pada setiap individu Owa jawa. Karakter vokalisasi yang dilihat dari struktur vokalisasi yang bervariasi antar individu tersebut akan menjadi identitas individu, dengan

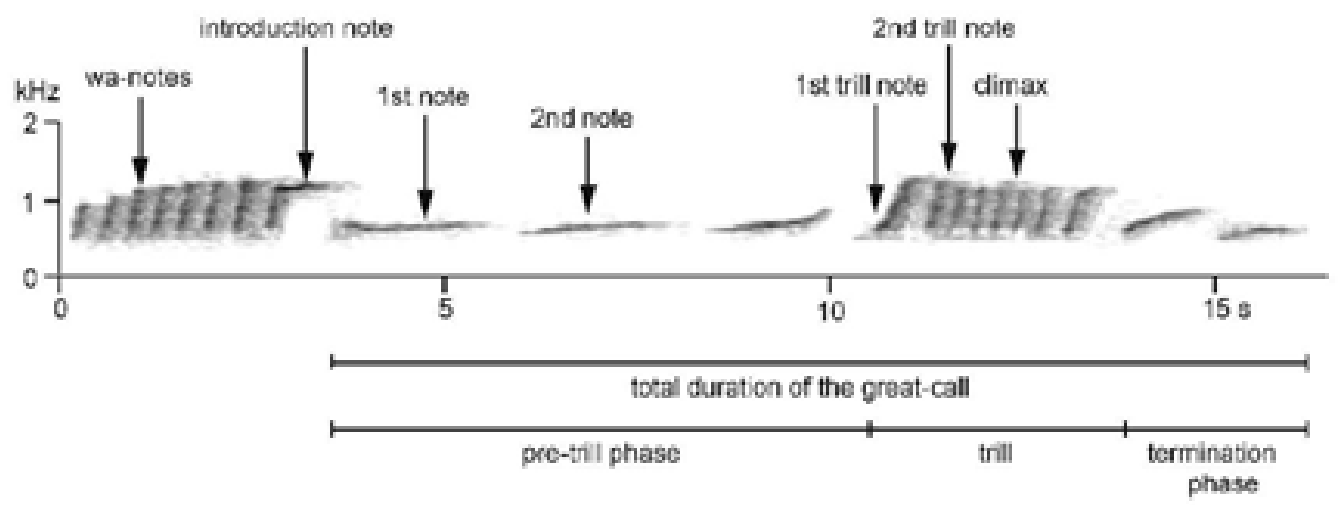

Gambar 1. Sonogram fase great call Owa jawa betina (Dallmann dan Geissmann, 2009)

begitu masing-masing kelompok akan mengetahui jarak antar kelompok dan wilayah kekuasaannya saat menandai teritorialnya dengan vokalisasi (Mitani, 1985 dalam Fan et al., 2007).

\section{METODE PENELITIAN}

Penelitian ini dilakukan pada tiga Listening post (LPs1: Hutan Sokokembang; LPs2: Hutan Kayupuring; LPs3: Hutan Jolotigo) di Hutan Lindung Petungkriyono, Pekalongan, Jawa Tengah. Penelitian ini dilaksanakan pada bulan Agustus-September 2015. Metode yang digunakan dalam penelitian ini adalah deskriptif dengan teknik Focal Continuous Sampling (Altmann, 1974). Data vokalisasi direkam menggunakan mikrofon (Shotgun directional mic) Rhode NTG 2 yang dilekatkan pada alat rekam suara Sony ICD-PX333. Data vokalisasi dianalisis menggunakan software Raven Pro 1.4 setelah sebelumya dilakukan konversi data dari mp3 ke format wav menggunakan Adobe Audition 3.0.

Song bout betina Owa jawa memiliki beberapa great call, tipe vokalisasi tersebut cukup panjang dan sangat menstandarisasi perbendaharaan suara pada Owa jawa betina (Haimoff dan Tilson, 1985 dalam Dallmann dan Geissmann, 2009). Selain itu, great call pada Owa jawa dapat mewakili kelompok Owa jawa (Dallmann dan Geissmann, 2009). Dallmann dan Geissmann (2009) membagi great call menjadi 3 bagian, yaitu fase pre-trill, trill 
dan fase terminasi (Gambar 1). Terdapat beberapa variabel vokalisasi yang akan dianalisis dalam penelitian ini (Tabel $1)$.

Semua data variabel vokalisasi dianalisis secara statistik. Rasio coefficients of variance (CV) intra individu dan antar individu yang memiliki nilai $<1$ akan menunjukkan bahwa variabel tersebut bervariasi antar individu

Tabel 1. Deskripsi variabel vokalisasi yang dianalisis

\begin{tabular}{|c|c|c|}
\hline No. & Variabel (satuan) & Deskripsi \\
\hline 1 & Total durasi great call (s) & $\begin{array}{l}\text { Interval waktu antara mulainya note pertama hingga note } \\
\text { terakhir great call }\end{array}$ \\
\hline 2 & Durasi great call tanpa terminasi (s) & No. 1 minus No. 35 \\
\hline 3 & Durasi fase trill (s) & No. 1 minus (No. 11 plus No. 35 ) \\
\hline 4 & Jumlah note seluruh great call & $\begin{array}{l}\text { Jumlah note antara note pertama dan note terakhir great } \\
\text { call }\end{array}$ \\
\hline 5 & Rentang frekuensi great call (Hz) & No. 7 minus No. 9 \\
\hline 6 & Jumlah note dengan frekuensi maksimal & Jumlah note dengan frekuensi tertinggi \\
\hline 7 & Frekuensi maksimal $(\mathrm{Hz})$ & Frekuensi tertinggi dalam great call \\
\hline 8 & Jumlah note dengan frekuensi minimal & Jumlah note dengan frekuensi terendah \\
\hline 9 & Frekuensi minimal $(\mathrm{Hz})$ & Frekuensi terendah dalam great call \\
\hline 10 & Jumlah note fase pre-trill & $\begin{array}{l}\text { Jumlah note antara note pertama dan note terakhir sebe- } \\
\text { lum trill }\end{array}$ \\
\hline 11 & Durasi fase pre-trill (s) & $\begin{array}{l}\text { Waktu antara mulainya note pertama dan mulainya note } \\
\text { pertama trill }\end{array}$ \\
\hline 12 & Durasi introduction note (s) & Lama nya waktu yang dibutuhkan introduction note \\
\hline 13 & Rentang frekuensi introduction note $(\mathrm{Hz})$ & No. 15 minus No. 14 \\
\hline 14 & Frekuensi minimal introduction note $(\mathrm{Hz})$ & Frekuensi terendah pada introduction note \\
\hline 15 & Frekuensi maksimal introduction note $(\mathrm{Hz})$ & Frekuensi terendah pada introduction note \\
\hline 16 & Durasi note $1(\mathrm{~s})$ & Durasi note pertama pada great call \\
\hline 17 & Rentang frekuensi note $1(\mathrm{~Hz})$ & No. 19 minus No. 18 \\
\hline 18 & Minimal frekuensi note $1(\mathrm{~Hz})$ & Frekuensi terendah pada note pertama great call \\
\hline 19 & Maksimal frekuensi note $1(\mathrm{~Hz})$ & Frekuensi tertinggi pada note pertama great call \\
\hline 20 & Durasi note $2(\mathrm{~s})$ & Durasi note kedua pada great call \\
\hline 21 & Rentang frekuensi note $2(\mathrm{~Hz})$ & No. 23 minus No. 22 \\
\hline 22 & Minimal frekuensi note $2(\mathrm{~Hz})$ & Frekuensi terendah pada note kedua great call \\
\hline 23 & Maksimal frekuensi note $2(\mathrm{~Hz})$ & Frekuensi tertinggi pada note kedua great call \\
\hline 24 & Durasi trill note $1(\mathrm{~s})$ & Durasi note pertama fase trill \\
\hline 25 & Rentang frekuensi trill note $1(\mathrm{~Hz})$ & No. 27 minus No. 26 \\
\hline 26 & Minimal frekuensi trill note $1(\mathrm{~Hz})$ & Frekuensi terendah pada note pertama trill \\
\hline 27 & Maksimal frekuensi trill note $1(\mathrm{~Hz})$ & Frekuensi tertinggi pada note pertama trill \\
\hline 28 & Durasi trill note $2(\mathrm{~s})$ & Durasi note kedua fase trill \\
\hline 29 & Rentang frekuensi trill note $2(\mathrm{~Hz})$ & No. 31 minus No. 30 \\
\hline 30 & Minimal frekuensi trill note $2(\mathrm{~Hz})$ & Frekuensi terendah pada note kedua trill \\
\hline 31 & Maksimal frekuensi trill note $2(\mathrm{~Hz})$ & Frekuensi tertinggi pada note kedua trill \\
\hline 32 & Jumlah note fase trill & No. 4 minus (No. 10 plus No. 36 ) \\
\hline 33 & Frekuensi minimal pada note akhir trill $(\mathrm{Hz})$ & Frekuensi terendah pada akhir note trill \\
\hline 34 & Rentang frekuensi minimal pada fase trill $(\mathrm{Hz})$ & Frekuensi minimal dalam fase trill \\
\hline 35 & Durasi fase terminasi (s) & $\begin{array}{l}\text { Waktu dari note pertama hingga note terakhir fase termi- } \\
\text { nasi }\end{array}$ \\
\hline 36 & Jumlah note fase terminasi & Jumlah note dalam fase terminasi \\
\hline
\end{tabular}

Sumber: Dallmann dan Geissmann (2009) 
dan menunjukkan bahwa terdapat variasi struktur vokalisasi pada tiap individu Owa jawa. Kekhasan antar individu dianalisis menggunakan Discriminant Function Analysis (DFA). DFA menghasilkan fungsi diskriminan kanonikal yang mewakili kombinasi linear dari variabel asli yang memisahkan kelompok secara maksimal (Nelson dan Marler,
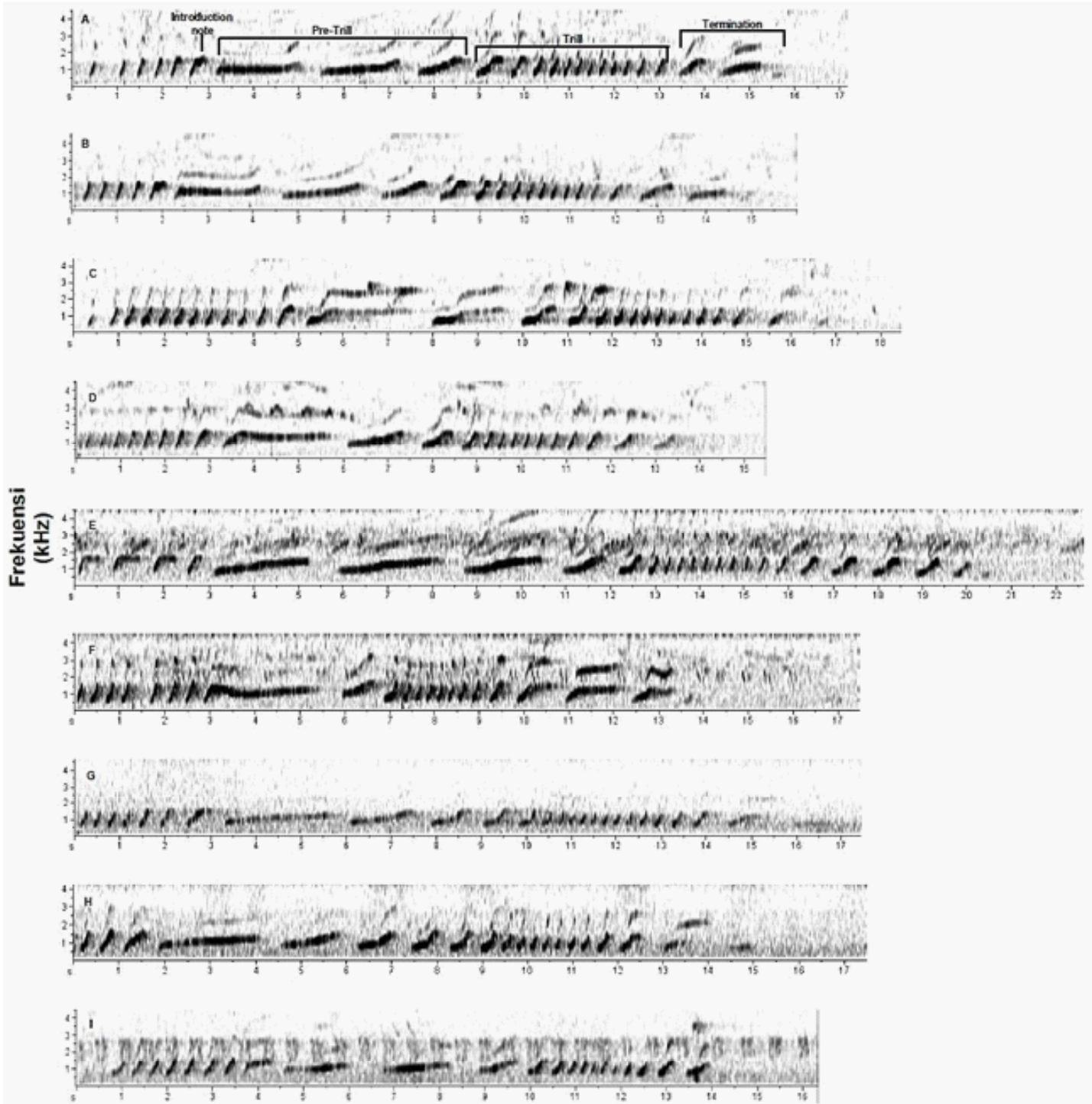

Waktu (s)

Gambar 2. Sonogram great call sembilan individu Owa jawa betina (A - I) yang menjadi perwakilan tiap kelompok.

1990 dalam Bee et al., 2001). Karena variabel-variabel tersebut memiliki korelasi yang tinggi, sehingga dibentuk suatu faktor analisis melalui Principal Component Analysis (PCA). Digunakan SPSS 17.0 untuk menguji statistik tersebut.

\section{HASIL DAN PEMBAHASAN}

Satwa memiliki kemampuan untuk membedakan dan mengenali individu lain dari tingkat sejenis atau tingkat organisasi lainnya (Colgan, 1983 dalam Bee et al., 2001). Vokalisasi dijadikan media untuk berkomunikasi antar individu dalam kelompok, berbeda kelompok atau bahkan berbeda jenis. Jika suatu individu mampu untuk 
Tabel 2. Hasil Discriminant Function Analysis (DFA) pada variabel vokalisasi Great call individu betina Owa jawa

\begin{tabular}{lllll} 
Function & Eigenvalue & \% of Variance & $\begin{array}{l}\text { Wilks'Lamda sig. } \\
\text { Test. Of function }\end{array}$ & $\begin{array}{c}\text { Korelasi } \\
\text { kanonikal }\end{array}$ \\
\hline 1 & 9,583 & 46,6 & 0,000 & 0,952 \\
2 & 3,224 & 15,7 & 0,002 & 0,874 \\
3 & 2,733 & $\mathbf{1 3 , 3}$ & $\mathbf{0 , 0 1 0}$ & $\mathbf{0 , 8 5 6}$ \\
4 & $\mathbf{1 , 9 2 0}$ & $\mathbf{9 , 3}$ & $\mathbf{0 , 0 3 8}$ & $\mathbf{0 , 8 1 1}$ \\
$\mathbf{5}$ & $\mathbf{1 , 4 2 0}$ & $\mathbf{6 , 9}$ & $\mathbf{0 , 1 1 1}$ & $\mathbf{0 , 7 6 6}$ \\
$\mathbf{6}$ & $\mathbf{0 , 8 1 6}$ & $\mathbf{4 , 0}$ & $\mathbf{0 , 2 6 9}$ & $\mathbf{0 , 6 7 0}$ \\
7 & $\mathbf{0 , 6 1 2}$ & $\mathbf{3 , 0}$ & $\mathbf{0 , 4 8 8}$ & $\mathbf{0 , 6 1 6}$ \\
$\mathbf{8}$ & $\mathbf{0 , 2 7 1}$ & $\mathbf{1 , 3}$ & $\mathbf{0 , 7 8 7}$ & $\mathbf{0 , 4 6 2}$ \\
\hline
\end{tabular}

mengidentifikasi individu yang lainnya melaui panggilan, maka penerima akan mengikuti pada meningkatnya kemampuan untuk mengikuti detail yang lebih baik pada struktur panggilan. Fitur panggilan berpotensi tidak hanya sebagai pengenal individual tapi memungkinkan untuk diskriminasi lebih detail seperti mengetahui kualitas fisik dari pasangan atau saingan (Barnard dan Burk, 1979 dalam Terleph et al., 2015).

Selama penelitian didapatkan sebanyak 107 great call dari 9 individu Owa betina ( 5 - 24 great call tiap individu) di ketiga listening post yang berbeda. Studi ini menunjukan bahwa great call Owa betina berbeda secara statistik pada antar individu yaitu sebesar 94,4\%. Studi pada jenis Owa lainnya yaitu Hylobates lar (Terleph et al., 2015) juga menunjukan bahwa great call menjadi panggilan yang dapat membedakan antar individu dengan nilai klasifikasi sebesar $83,5 \%$ dari 14 betina $\mathrm{H}$. lar. Tabel 2 merupakan hasil analisis fungsi diskriminan yang menunjukan fungsi 1 dan fungsi 2 memiliki nilai persentase variasi tertinggi, sehingga digunakan untuk melihat faktor loading (hasil PCA) yang menunjukan faktor mana yang memuat lebih berat variabel vokalisasi yang berkontribusi dalam pembeda antar individu. Faktor 1 dan 2 (fungsi 1), serta faktor 5 dan 14 (fungsi 2) memuat lebih berat pada variabel

Tabel 3. Klasifikasi fungsi diskriminan dari variabel vokalisasi individu Owa jawa betina

\begin{tabular}{lllllllllll} 
Individu & \multicolumn{1}{c}{} & \multicolumn{1}{c}{ Predicted Group Membership } & \% Correct \\
\hline & A & B & C & D & E & F & G & H & I & \\
A & 21 & 1 & 0 & 0 & 1 & 0 & 1 & 0 & 0 & 87,5 \\
B & 0 & 12 & 0 & 0 & 0 & 0 & 0 & 0 & 0 & 100 \\
C & 0 & 0 & 13 & 0 & 0 & 0 & 0 & 0 & 0 & 100 \\
D & 0 & 0 & 0 & 6 & 1 & 0 & 0 & 0 & 0 & 85,7 \\
E & 0 & 0 & 0 & 1 & 8 & 0 & 0 & 0 & 0 & 88,9 \\
F & 0 & 0 & 0 & 0 & 0 & 16 & 0 & 0 & 0 & 100 \\
G & 0 & 0 & 0 & 0 & 0 & 0 & 5 & 1 & 0 & 83,3 \\
H & 0 & 0 & 0 & 0 & 0 & 0 & 0 & 15 & 0 & 100 \\
I & 0 & 0 & 0 & 0 & 0 & 0 & 0 & 0 & 5 & 100 \\
& & & & & & & & & & $101 / 107=94,4$ \\
\hline
\end{tabular}

total durasi great call, total durasi great call tanpa terminasi, durasi introduction note, rentang frekuensi introduction note, frekuensi minimal introduction note, frekuensi maksimal introduction note, minimal frekuensi pada trill note 2 , frekuensi minimal pada note akhir trill, dan rentang frekuensi minimal pada fase trill, menjadi variabel vokalisasi yang paling berkontribusi dalam pembeda antar individu. 
Variabel - variabel vokalisasi tersebut lebih bervariasi pada tingkat antar individu dibandingkan intraindividu. Jika berdasarkan mean dari koefisien variasi intra-individu, variabel - variabel tersebut memiliki tipe dinamis yang artinya setiap variabel cenderung berubah-ubah pada setiap individu (tabel 4). Tipe variabel vokalisasi bisa dijadikan sarana untuk identifikasi jenis atau individu (Gerhardt, 1991). Begitupun dalam studi yang dilakukan oleh Bee et al.(2001) yang menyebutkan bahwa properti suara yang bertipe dinamis lebih bervariasi antar individu dibandingkan properti suara yang bertipe statis yang menjadi ciri bagi suatu jenis. Dalam studi ini, variabel yang

Tabel 4. Mean, SD, dan variabilitas intra-individu dan antar individu $(\mathrm{CV})$ untuk 36 variabel vokalisasi great call Owa jawa

\begin{tabular}{|c|c|c|c|c|c|c|c|}
\hline No. & Grand Mean & $S D$ & Tipe* & $\begin{array}{l}\text { Mean } C V \\
\text { intra-indi- } \\
\text { vidu }(\%)\end{array}$ & $\begin{array}{l}\text { Rentang CV } \\
\text { intra-individu } \\
(\%)\end{array}$ & $\begin{array}{l}\text { CV antar } \\
\text { individu (\%) }\end{array}$ & Rasio $\mathrm{CVb} / \mathrm{CVw}$ \\
\hline 1 & 11,06 & 2,04 & Intermediet & 11,96 & $5,87-27,13$ & 18,45 & 1,54 \\
\hline 2 & 8,32 & 1,79 & Dinamis & 14,78 & $6,36-27,77$ & 21,53 & 1,46 \\
\hline 3 & 3,37 & 0,88 & Dinamis & 19,14 & $12,16-36,96$ & 26,02 & 1,36 \\
\hline 4 & 15,22 & 2,46 & Intermediet & 11,47 & $7,78-21,23$ & 16,17 & 1,41 \\
\hline 5 & 1447,67 & 104,28 & Intermediet & 6,69 & $4,37-10,09$ & 7,20 & 1,08 \\
\hline 6 & 1,77 & 1,34 & Dinamis & 62,39 & $0,00-133,33$ & 76,03 & 1,22 \\
\hline 7 & 1744,35 & 92,45 & Statis & 3,63 & $2,08-6,45$ & 5,30 & 1,46 \\
\hline 8 & 1,63 & 1,14 & Dinamis & 58,40 & $32,55-81,49$ & 69,92 & 1,20 \\
\hline 9 & 297,19 & 79,72 & Dinamis & 23,28 & $11,55-38,24$ & 26,83 & 1,15 \\
\hline 10 & 2,66 & 0,53 & Intermediet & 9,64 & $0,00-24,00$ & 19,94 & 2,07 \\
\hline 11 & 4,85 & 1,04 & Dinamis & 13,75 & $4,37-26,73$ & 21,37 & 1,55 \\
\hline 12 & 0,47 & 0,29 & Dinamis & 58,09 & $27,70-168,43$ & 60,07 & 1,03 \\
\hline 13 & 983,26 & 503,21 & Dinamis & 43,41 & $9,21-153,74$ & 51,18 & 1,18 \\
\hline 14 & 349,28 & 194,65 & Dinamis & 49,45 & $8,45-154,27$ & 55,73 & 1,13 \\
\hline 15 & 1332,54 & 667,10 & Dinamis & 40,53 & $3,02-153,48$ & 50,06 & 1,24 \\
\hline 16 & 2,30 & 0,39 & Dinamis & 12,09 & $6,65-17,43$ & 16,96 & 1,40 \\
\hline 17 & 1101,63 & 145,15 & Intermediet & 11,54 & $6,07-17,96$ & 13,18 & 1,14 \\
\hline 18 & 425,02 & 88,25 & Dinamis & 18,71 & $14,06-23,06$ & 20,76 & 1,11 \\
\hline 19 & 1526,65 & 126,81 & Intermediet & 6,43 & $3,09-9,36$ & 8,31 & 1,29 \\
\hline 20 & 1,31 & 0,44 & Dinamis & 19,87 & $8,08-44,66$ & 33,64 & 1,69 \\
\hline 21 & 1141,94 & 172,46 & Intermediet & 11,37 & $5,20-27,53$ & 15,10 & 1,33 \\
\hline 22 & 483,17 & 95,69 & Dinamis & 15,29 & $7,92-29,09$ & 19,80 & 1,30 \\
\hline 23 & 1625,11 & 198,80 & Intermediet & 7,10 & $2,39-27,09$ & 12,23 & 1,72 \\
\hline 24 & 0,47 & 0,17 & Dinamis & 26,48 & $17,79-42,31$ & 37,10 & 1.40 \\
\hline 25 & 1248,12 & 121,57 & Intermediet & 8,64 & $2,10-14,40$ & 9,74 & 1,13 \\
\hline 26 & 452,56 & 71,82 & Dinamis & 13,88 & $10,81-22,40$ & 15,87 & 1,14 \\
\hline 27 & 1700,67 & 111,13 & Statis & 4,97 & $2,97-7,80$ & 6,53 & 1,31 \\
\hline 28 & 0,30 & 0,14 & Dinamis & 26,93 & $18,16-55,49$ & 47,91 & 1,78 \\
\hline 29 & 1150,63 & 123,28 & Intermediet & 9,16 & $1,35-18,11$ & 10,71 & 1,17 \\
\hline 30 & 471,47 & 75,85 & Intermediet & 11,37 & $6,99-15,63$ & 16,09 & 1,42 \\
\hline 31 & 1622,10 & 108,01 & Intermediet & 5,12 & $1,49-8,77$ & 6,66 & 1,30 \\
\hline 32 & 9,63 & 1,99 & Dinamis & 16,68 & $10,64-26,22$ & 20,65 & 1,24 \\
\hline 33 & 432,16 & 80,55 & Dinamis & 16,54 & $11,19-28,34$ & 18,64 & 1,13 \\
\hline 34 & 395,34 & 68,78 & Dinamis & 14,83 & $4,55-24,82$ & 17,40 & 1,17 \\
\hline 35 & 2,44 & 0,98 & Dinamis & 25,31 & $15,46-38,60$ & 40,15 & 1,59 \\
\hline 36 & 2,99 & 0,77 & Dinamis & 23,58 & $13,44-35,36$ & 25,78 & 1,09 \\
\hline
\end{tabular}

Keterangan: *Determinasi berdasarkan Mean CV intra-individu (Gerhardt, 1991) 
bersifat statis yaitu pada variabel frekuensi maksimal dan frekuensi maksimal fase trill note 1. Variabel statis lebih sedikit bila dibandingkan dengan variabel yang bertipe dinamis. Great call yang memiliki struktur yang lebih bervariasi, menunjukkan bahwa setiap individu memiliki karakteristik yang berbeda dan hal tersebut baik untuk mendiskriminasi individu.

Struktur vokalisasi dari Female song bout Owa jawa terdiri dari wa-note, wa-phrase, dan rangkaian great call. Great call tersusun atas beberapa fase yaitu Pre-trill, trill dan terminasi. Great call merupakan bagian paling standar dan paling lama dalam pembendaharaan suara pada Owa betina (Haimoff dan Tilson, 1985 dalam Dallmann dan Geissmann, 2001). Durasi great call merupakan salah satu variabel vokalisasi yang bervariasi pada antar individu. Durasi dan jumlah dari setiap note pada setiap fase adalah berbeda disetiap great call tiap individu (gambar 2). Waktu yang dibutuhkan oleh individu Owa betina dalam melakukan great call berbeda-beda, secara umum betina membutuhkan waktu melakukan great call dalam rentang 8,99 - 13,53 s. Jumlah note pada setiap fase great call memungkinkan untuk menentukan durasi terbentuknya great call, seperti pada gambar 2 menunjukan bahwa sonogram great call individu $\mathrm{E}$ (gambar 2E) memiliki durasi lebih lama (16,98 s) bila dibandingkan dengan individu I (gambar 2I) yang hanya membutuhkan waktu sekitar 9,42 s, hal tersebut karena jumlah note setiap fase pada great call berbeda yaitu 4 note pre-trill, 12 note trill, dan 4 note terminasi untuk individu E, sedangkan pada individu I memiliki 3 note pre-trill, 9 note trill, dan 2 note trill.

Jarak antar kelompok juga memungkinkan untuk mempengaruhi pada durasi dan jumlah great call yang dikeluarkan. Geissmann dan Nijman (2001), menyebutkan bahwa kelompok Owa yang saling bertemu atau berdekatan, akan menyebabkan lamanya durasi dan sedikitnya jumlah great call yang dihasilkan pada setiap kelompoknya. Berbeda dengan Owa betina yang memiliki anakan betina yang mulai beranjak dewasa (bukan termasuk kelompok sampel). Selain itu, perilaku sosial juga memungkinkan untuk menimbulkan variasi pada struktur vokalisasi Owa jawa. Berdasarkan observasi lapangan, Owa betina tersebut melakukan great call lebih banyak dibandingkan dengan Owa yang sedang tidak memiliki anakan yang beranjak dewasa, hal tersebut kemungkinan disamping menandai daerah teritorial, sekaligus mengajarkan kepada anak bagaimana cara melakukan penanda teritorial menggunakan suara. Anak akan mengikuti rangkaian wa-notes hingga introduction note, tidak mengikuti hingga rangkaian great call seutuhnya. Menurut Cheyne et al.(2007), perilaku bersuara pada Owa terjadi karena meniru induknya.

Selain itu, bervariasinya variabel yang bersifat dinamis, dimungkinkan karena adanya faktor lain yang memainkan peran dalam dihasilkannya perbedaan akustik atau suara antar individu. Sebagai contoh, individu biasanya bervariasi dalam ukuran tubuh (Uehara dan Nishida, 1987 dalam Gamba dan Giacoma, 2010), dan perbedaan ukuran mungkin berkorelasi dengan mekanisme terbentuknya laring yang menyebabkan adanya perbedaan dalam fitur panggilan (Gouzoules dan Gouzoules, 1990 dalam Gamba dan Giacoma, 2010).

Ukuran laring, dan supralaringeal akan mempengaruhi frekuensi fundamental (Rendall et al., 1998 dalam Belin, 2006). Akan tetapi, dalam studi ini tidak dilakukan pengukuran tubuh pada Owa, sehingga belum bisa dipastikan bahwa faktor ukuran tubuh turut berkontribusi dalam bervariasinya struktur vokalisasi.

Selain itu, faktor geografi juga turut berkontribusi dalam pembeda individu pada populasi yang berbeda. Dallmann dan Geissmann (2009), menyebutkan dalam studinya mengenai beberapa populasi Owa jawa (Hylobates moloch) yang berada di Ujung Kulon, Gunung Halimun, Gunung Pangrango, dan Jawa Tengah (Gunung Lawet dan Linggo Asri) adalah berbeda berdasarkan great call pada tiap individu dalam populasi tersebut. Namun, perbedaan tersebut tidak sampai terbentuknya anak jenis karena belum terdapat data perbandingan untuk melihat seberapa besar 
“jarak vokal” yang dapat memisahkan suatu populasi untuk menjadi anak jenis yang berbeda. Dalam penelitian ini, pada tiga populasi kecil Owa jawa (LPs 1-3) juga menunjukkan adanya variasi struktur vokalisasi. Antar listening post terdapat barrier berupa jalan, bukit, dan sungai yang memungkinkan untuk menjadi batasan-batasan biogeografi.

Dalam studi ini menyebutkan bahwa variabel vokalisasi yang bertipe statis lebih sedikit dibandingkan tipe dinamis atau intermediet. Variabel dinamis bersifat temporal pada tiap individu, lain halnya dengan tipe statis. Oleh karena itu, tipe statis digunakan untuk mengidentifikasi suatu jenis. Frekuensi maksimal great call dalam studi ini memiliki tipe statis. Menurut Dallmann dan Geissmann (2009), rentang frekuensi great call Owa jawa berkisar antara 0,5 - 1,5 kHz yang dapat terdengar hingga $2 \mathrm{~km}$ (Cheyne et al., 2007). Adanya perbedaan posisi dari sembilan individu Owa jawa betina terhadap listening post tidak mempengaruhi frekuensi great call yang dihasilkan pada tiap individu. Posisi Owa jawa yang semakin jauh dari listening post, menjadikan note terbaca lemah atau halus saat dianalisis menggunakan software analisis suara.

Terdapat banyak faktor yang bisa menghambat transmisi suara. Sinyal suara dapat menjadi lemah karena beberapa faktor seperti daun-daunan, turbulansi udara, gradien suhu, efek permukaan dan vokalisasi dari satwa lain yang dapat menyerap, merefleksikan dan membiaskan gelombang suara (Whitten, 1982 dalam Wanelik, 2012). Posisi Owa jawa yang jauh dari listening post, sangat memungkinkan adanya tumpang tindih suara Owa jawa dengan background noise. Suara dari Tonggeret atau burung kicau (contoh: burung Tohtor Megalaima australis) bisa mendominasi dalam sonogram suara Owa jawa dari hasil analisis. Topografi dari hutan lindung Petungkriyono yang berbukit-bukit juga bisa membiaskan gelombang suara.

Cheyne (2008), menyebutkan bahwa satwa sangatlah sensitif terhadap perubahan lingkungan sehingga dapat berpengaruh terhadap perilaku satwa tersebut. Faktor meteorologi seperti hujan dan angin berpengaruh signifikan terhadap perilaku bersuara dari Hylobates albibarbis. Studi lain menyebutkan bahwa hujan menghambat perilaku bersuara pada Owa (Whitten, 1982 dalam Cheyne, 2008). Owa akan mengalami kehilangan panas tubuh saat terjadi hujan saat malam atau pagi harinya, sehingga Owa akan lebih memprioritaskan mencari asupan makanan terlebih dahulu dibandingkan menandai daerah teritori (Tenaza, 1976 dalam Cheyne, 2008).

Penelitian ini dilakukan pada saat musim kering atau kemarau. Selama kurun waktu penelitian hanya terjadi hujan satu kali yaitu saat malam hari. Berdasarkan fakta dilapangan, pagi hari setelah terjadinya hujan, terdapat beberapa kelompok Owa jawa ( $\mathrm{N}=2$ di LPs 2) tidak melakukan vokalisasi, sedangkan kelompok yang lainnya tetap melakukan vokalisasi dengan waktu permulaan bersuara yang tidak seperti biasanya. Hal tersebut sesuai dengan studi yang dilakukan oleh Cheyne et al. (2008), yang menyebutkan bahwa Owa cenderung akan mencari makan dibandingkan dengan melakukan vokalisasi untuk menandai daerah teritorial. Owa jawa akan mengalami kehilangan panas tubuh selama hujan berlangsung saat malam dan membutuhkan banyak energi untuk menormalkan suhu tubuhnya. Oleh karena itu, terjadinya hujan tidak berdampak pada perubahan struktur vokalisasi Owa jawa. Namun, suara bising yang dihasilkan hujan akan menghambat sinyal suara yang diberikan oleh Owa akan sulit atau tidak tersampaikan pada kelompok Owa lainnya sehingga tidak terjadi komunikasi yang efektif (Dooley et al., 2012). Begitupun dengan angin, angin yang bertiup ke arah yang berlawanan dengan alat rekam hanya membuat suara owa jawa lemah saat ditampilkan berupa sonogram dalam software analisis suara. Namun, tidak berpengaruh terhadap frekuensi yang dihasilkan oleh individu Owa jawa.

\section{KESIMPULAN}


Penelitian ini memiliki kesimpulan bahwa terdapat variasi struktur vokalisasi Owa jawa (Hylobates moloch Audebert, 1798) di hutan lindung Petungkriyono, Pekalongan, Jawa Tengah. Variasi tersebut ditandai oleh durasi dan frekuensi introduction note, durasi great call dan frekuensi minimal pada fase trill dalam great call yang berbeda pada setiap individu. Durasi introduction note pada 9 Owa jawa betina bervariasi antara 0,147-0,612 s dengan rentang frekuensi 408,54-1209,6 Hz dan rentang fekuensi minimal fase trill $328,015-467,9 \mathrm{~Hz}$, serta durasi total great call 8,99 - 13,53 s dengan rentang frekuensi 195,47-1823,38 Hz.

\section{DAFTAR PUSTAKA}

Altmann, J. 1974. Observational Study of Behavior: Sampling Methods. Behaviour 49, 227-267

Arini, K., Noer, M. I., Wulandari, A., Amalia, R., \& Auliandina, T. (2016). Temporal and spectral variation in advertisement call of males Microhyla achatina (Tschudi, 1838) are sufficient for individual discrimination. AIP Conference Proceedings, 1744, 20032.

Bee, Mark A., Carol E.K., Kelle J.B., dan H. Crl G. 2001. Individual variation in advertisment calls of territorial male green frogs, Rana clamitans: implication for individual discrimination. Ethology 107, 65-84.

Belin, Pascal. 2006. Voice processing in human and non-human primates. Philosophical Transactions The Royal Society B 361, 2091-2107

Cheyne, Susan M. 2008. Effects of meteorology, Astronomical variable, location and human disturbance on singing apes: Hylobates albibarbis. American journal of primatology 70,386-392.

Cheyne, Susan M., Chivers, David J., dan Sugardjito J. 2007. Covarvariation in the great calls of rehabititant and wild gibbons (Hylobates albibarbis). The raffles bulletin of zoology 55(1), 201-207

Chivers D.J. 1974. The Siamang in Malaya: a field study of a primate in tropical rainforest. Contributions of primatology, vol. 4, 1-335

Dallmann, R. dan Thomas Geissmann. 2001. Individuality in the female songs of wild silvery gibbons (Hylobates moloch) on Java, Indonesia. Contributions to Zoology, 70, 41-50.

Dallmann,R. dan Thomas Geissmann. 2009. Individual and Geographical Variability in the Songs of Wild Silvery Gibbons (Hylobates moloch) on Java, Indonesia. The Gibbons, New Persepectives on small ape socioecology and population biology, 91-109

Dooley, H. M., D. S. Judge, dan L. H. Schmitt. 2012. Singing by Male and Female Kloss Gibbons (Hylobates klossii) in the Peleonan Forest, Siberut Island, Indonesia. Primates 54, 39-48

Fan, Pengfei, Cangming Liu, Wenshou Luo, dan Xuelong Jiang. 2007. Can a group elicit duets from its neighbours? A field study on the black-crested gibbon (Nomascus concolor jingdongensis) in central Yunnan, China. Folia Primatology 78, 186-195.

Gamba, Marco dan Cristina Giacoma. 2010. Key Issues In The Study Of Primate Acoustic Signal, An Update. Journal Of Anthropological Science vol.88, 215-220

Geissmann, T. dan V. Nijman. 2001. Calling Behaviour of Wild Javan Gibbons Hylobates moloch In Java, Indonesia dalam Forest (and) Primates. Conservation and ecology of the endemic primates of Java and Borneo. Tropenbos Kalimantan Series.

Gerhardt, H. Carl. 1991. Female mate in tree frogs: static and dynamic acoustic criteria. Animal Behaviour 42, 615- 
635

Seyfarth, R.M., Dorothy L. Cheney, Thore Bergman, Julia Fischer, Klaus Zuberbuhler, dan Kurt H. 2010. The central importance of information in studies of animal communication. Essay. Animal behaviour, 80, 3-8

Terleph, Thomas A., S. Malaivijitnond, U.H Reichard. 2015. Lar Gibbon (Hylobates lar) Great Call Reveals Individual Caller Identity. American Journal of Primatology. 2-10

Wanelik, Klara M., Abdul Azis, dan Susan M. Cheyne. 2012. Note-, Phrase- and Song-Spesific Acoustic Variables Contributing To The Individuality of Male Duet Song In The Bornean Southern Gibbon (Hyobates albibarbis). Primates.

Whittaker, J. Danielle. 2005. New population estimates for the endemic Kloss's gibbon Hylobates klossii on the Mentawai Island, Indonesia.Oryx vol.39(4), 458-461. 